\title{
Hubungan Jumlah Tayangan Iklan Penawaran Penjualan dan Penyewaan Properti dengan PDRB Provinsi Bali Tahun 2019-2021 Dengan Menggunakan Big Data : Web Scraping
}

\author{
(Relationship Property Sales and Rent Advertisement Impressions with PDRB in Bali Province year \\ 2019-2021 with Big Data Approach : Web Scraping) \\ M. Tharif Arkandana ${ }^{1}$, Thosan Girisona Suganda ${ }^{2}$, Setia Pramana ${ }^{1,2}$ \\ ${ }^{1}$ Prodi Komputasi Statistik, Politeknik Statistika STIS, Jakarta \\ ${ }^{2}$ Direktorat Analisis dan Pengembangan Statistik, Badan Pusat Statistik, Jakarta \\ Jalan Otto Iskandardinata No.64C 14, RT.1/RW.4, Bidara Cina, Kecamatan Jatinegara, Kota Jakarta Timur, Daerah \\ Khusus Ibukota Jakarta 13330 \\ E-mail: ${ }^{1} 221810402 @$ stis.ac.id, ${ }^{2}$ thosan.suganda@bps.go.id, ${ }^{1,2}$ setia.pramana@stis.ac.id
}

\begin{abstract}
ABSTRAK
Ekonomi sangat berpengaruh untuk memajukan kehi dupan di suatu negara, namun diakibatkan oleh pandemi virus Covid-19 kondisi ekonomi negara menjadi tidak stabil. Beberapa sektor seperti pariwisata, penurunan pertumbuhan ekonomi seperti PDRB. Berdasarkan data Badan Pusat Statistik (BPS) Provinsi Bali PDRB menurun secara signifikan pada tahun 2020 triwulan keempat yaitu hingga $-12,21 \%$. Penelitian ini menggunakan metode analisis hubungan atau korelasi antara data PDRB dan TPK hotel dengan data tayangan iklan penjualan dan penyewaan properti di Provinsi Bali, dimana data didapatkan dengan menggunakan Big Data dengan metode web scraping salah satu situs web properti di Indonesia (rumah123.com). Secara hubungan antara PDRB dan tayangan iklan didapatkan hasil -0.64 dan -0.67 menunjukkan harga jual dan sewa sektor properti mengalami tekanan dan berdampak pada pemulihan pasar properti dan tayangan iklan menaik, sedangkan pada TPK dihasilkan -0.53 menunjukkan pendapatan pada sektor pariwisata sudah cukup naik maka iklan penjualan akan menurun, karena pariwisata adalah sumber pendapatan yang cukup potensial di Bali.
\end{abstract}

Kata kunci: Ekonomi, PDRB, korelasi, pandemi

\begin{abstract}
The economy is very influential in advancing life at country, but due to the Covid-19 virus pandemic, the country's economic condition has become unstable. Some sectors such as tourism, the decline in economic growth such as GDP. Based on data from the Central Statistics Agency (BPS) of Bali Province, GRDP decreased significantly in the fourth quarter of 2020, reaching -12.21\%. This study uses a relationship or correlation analysis method between hotel GRDP and TPK data with property sales and rental advertising display data in Bali Province, where data is obtained using Big Data with the web scraping method of one of the property websites in Indonesia (rumah123.com). In terms of the relationship between GRDP and advertising impressions, the results are -0.64 and -0.67 indicating that the selling and rental prices of the property sector are under pressure and have an impact on the recovery of the property market and increased advertising impressions, while the TPK is -0.53 indicating that the income in the tourism sector has increased enough, so advertising sales will decline, because tourism is a potential source of income in Bali.
\end{abstract}

Keywords: economic, PDRB, correlation, pandemic

\section{PENDAHULUAN}

Ekonomi negara sangat berpengaruh untuk memajukan dan melanjutkan kehidupan di suatu negara agar dapat bersaing ataupun memenuhi kebutuhan masyarakat di negara tersebut. Ekonomi di Indonesia masih berada dalam kondisi yang belum stabil diakibatkan oleh pandemi virus Covid-19 yang dialami oleh negara kita tercinta ini. Sejak awal pandemi Covid-19 yang ditetapkan oleh WHO pada tanggal 12 Februari 2020. Dampak yang telah dirasakan yaitu terdapat dalam beberapa sektor seperti pariwisata, akomodasi, transportasi, retail, penurunan pertumbuhan ekonomi (Eddy Roflin, 2021).

Kekuatan ekonomi meliputi : pertumbuhan ekonomi; pertumbuhan pendapatan dan distribusi pendapatan relatif yaitu ukuran relatif dan pertumbuhan kelas menengah, tingkat pengangguran; produk domestik bruto dan rata-rata upah tahunan; tingkat kemiskinan, ketersediaan kredit, nilai tukar, dan suku bunga (Utama, 2016). Dari segi teknologi, yaitu di zaman serba digital atau maya ini semua bisa diakses oleh internet, seperti menjual dan menyewakan rumah dengan situs di internet, sehingga masyarakat lebih mudah untuk menayangkan iklan 
produknya untuk di bagikan kemanapun. Selain itu teknologi yang digunakan untuk pemasaran bisa mendapatkan harga yang lebih strategis untuk menanggapi kebutuhan dari pelanggan dan terdapat nilai tertentu untuk meningkatkan loyalitas pelanggan (Utama, 2016).

Berdasarkan data Badan Pusat Statistik (BPS) Provinsi Bali jumlah kunjungan wisatawan mancanegara (wisman) ke Provinsi Bali selama dua tahun terakhir (2019 dan 2020) mengalami penurunan. Pada tahun 2019, tercatat sebanyak 6.275.210 kunjungan wisman, angka ini menurun secara signifikan menjadi 1.069.473 kunjungan pada tahun 2020 kemudian hingga pada triwulan pertama dari tahun 2021 tercatat masih mengalami penurunan yaitu sebesar 43 kunjungan wisman, yaitu data ini dibagi menjadi dua pintu masuk yaitu pintu masuk udara dan laut, Bandara Ngurah Rai dan Pelabuhan Benoa.

Berdasarkan kunjungan wisman yang sudah dijelaskan sebelumnya maka ekonomi sektor pariwisata di Bali cukup menurun juga secara signifikan dan hal ini sudah di tunjukkan pada data PDRB dari Badan Pusat Statistik (BPS) yaitu pada triwulan pertama sampai keempat menunjukkan angka yang stabil yaitu berada pada angka tahunannya $5,60 \%$, kemudian pada tahun 2020 pada triwulan pertama mengalami penurunan sebesar $1,20 \%$ dan pada triwulan kedua dan selanjutnya sangat berubah menurun secara signifikan yaitu sebesar $11,06 \%$ selanjutnya $-12,32 \%$ dan $-12,21 \%$. Banyaknya hotel dan tempat wisata tutup juga tidak menutup kemungkinan untuk dijadikan dampak yang sangat berpengaruh secara signifikan di Provinsi Bali, berdasarkan data Badan Pusat Statistik yaitu Tingkat Penghunian Kamar (TPK) rata-rata per triwulan dari tahun 2019 yaitu menurun secara signifikan pada awal triwulan tahun 2020 dari angka 43,56 ke 2,45.

Berdasarkan permasalahan yang sudah dijelaskan sebelumnya, penelitian ini bertujuan untuk meneliti lebih lanjut mengenai hubungan antara pendapatan atau pertumbuhan ekonomi di Provinsi Bali terhadap tayangan iklan penjualan dan penyewaan properti di salah satu platform di Indonesia. Selain itu penelitian ini bertujuan untuk melihat aktivitas masyarakat selama pandemi terkhusus keuangan mereka dilihat dari penjualan atau penyewaan rumah. Ekonomi Indonesia semasa pandemi berada dalam kondisi yang tidak stabil dan cenderung menurun, dengan mengetahui aktivitas masyarakat apakah akan menambahkan pendapatannya dengan cara menjual dan menyewakan properti rumah atau tidak dan juga berdasarkan harganya. Dengan dilakukannya penelitian ini diharapkan dapat dijadikan referensi untuk memulihkan ekonomi di Provinsi Bali serta menemukan solusi yang tepat untuk memulihkannya.

\section{METODE}

\section{Data dan Sumber Data}

Data didapatkan dengan menggunakan metode web scraping yang dilakukan oleh Mariel, Khairunnisah, Panuntun, \& Pramana, (2021), untuk mengekstrak informasi detail dari tayangan iklan properti dari salah satu platform atau situs web yang menayangkan iklan penjualan dan penyewaan properti di Indonesia (rumah123.com). Data diambil secara berkala dari bulan April sampai dengan Juni tahun 2021 dan didapatkan sebanyak 25 variabel dan 371.753 baris data, kemudian daripada itu peneliti hanya menggunakan 11 variabel, yaitu dengan deskripsi sebagai berikut :

Tabel 1. Daftar Variabel dan Deskripsinya.

\begin{tabular}{cc}
\hline Variabel & Deskripsi \\
\hline Id & Angka unik per iklan \\
Channel & Jenis Transaksi (Jual atau sewa) \\
Property Id & Id properti tiap iklan \\
Property Type & Tipe properti \\
Province & Provinsi tempat properti \\
Regency & Kota atau kabupaten tempat properti \\
Certificate & Jenis sertifikat yang dimiliki properti \\
Completion Date & Tanggal iklan tayang \\
Price & Harga properti \\
Transacted & Keterangan sudah terjual, tersewa, atau belum \\
Update Timestamp & Tanggal scraping dilakukan \\
\hline
\end{tabular}




\section{Metode Analisis Data}

Penelitian ini dilakukan menggunakan pendekatan kuantitatif dengan metode korelasi atau mencari suatu hubungan antara jumlah tayangan iklan penjualan dan penyewaan properti di provinsi Bali dengan beberapa variabel yaitu diantaranya nilai rata-rata tingkat penghunian kamar (TPK) per triwulan, PDRB penyediaan akomodasi dan makan minum, dan PDRB jasa lainnya. Analisis data dimulai dengan melakukan cleaning, preprocessing, visualization, dan Descriptive Analysis.

1) Data Cleaning : sebelum data diproses lebih lanjut, data akan dibersihkan terlebih dahulu seperti melihat satu per satu variabel yang tidak memnuhi atau terdapat nilai yang tidak lengkap Kemudian data dilakukan pengkodean ulang di variabel regency yaitu kabupaten/kota karena terdapat kesalahan penamaan atau salah letak, dikarenakan di Bali terdapat kota Pemerintahan dan ibukota , tetapi yang akan dihitung adalah sesuai dengan administrasi pemerintahannya. Contohnya seperti Nusa Lembongan akan diganti menjadi Kabupaten Klungkung karena letaknya terdapat pada Kabupaten Klungkung secara administrasi pemerintahannya. Kemudian setelah sudah dilakukan pengkodean ulang, terdapat data yang masih terdapat nilai NULL didalamnya seperti luas area atau tanah dan harga dari properti tersebut, tetapi pada data tersebut didapatkan Ketika di-filter sesuai dengan tipe properti didapatkan hasil untuk tipe properti apartemen tidak memiliki nilai luas area atau tanah maka peneliti persempit lagi menjadi tipe properti hanya digunakan untuk tipe rumah

2) Data Prepocessing : Setelah dilakukan data cleaning, sebelum data diolah secara deskriptif, data melewati beberapa tahapan preprocessing diantaranya filtrasi, karena data yang dikumpulkan adalah data seluruh Indonesia maka untuk peneitian ini data tersebut di-filter berdasarkan provinsi Bali dan properti yang belum terjual sampai dengan tanggal scraping dilakukan dan kemudian data di-filter sesuai tanggal iklan yaitu pada triwulan pertama tahun 2019 sampai dengan triwulan pertama tahun 2021. Setelah data di-filter didapatkan 31.322 baris atau tayangan iklan.

. Kemudian peneliti mengkategorikan bangunan sesuai dengan luas area atau tanah dengan menggunakan nilai kuartil yaitu sebagai berikut :

Tabel 2. Kategori Luas Bangunan (Rumah).

\begin{tabular}{cc}
\hline Kategori & Jenis Bangunan (rumah) \\
\hline Sangat Luas $\left(\geq 400 \mathrm{~m}^{2}\right)$ & Villa Besar, long stay hotel \\
Cukup Luas $\left(\geq 135 \mathrm{~m}^{2} \&<400 \mathrm{~m}^{2}\right)$ & Rumah Modern, Rumah Besar, Private Villa, \\
Kurang Luas $\left(<135 \mathrm{~m}^{2}\right)$ & Rumah cantik dan minimalis, Rumah Semi Villa, \\
\hline
\end{tabular}

3) Descriptive Analysis

Analisis deskriptif yaitu meringkas atau menggambarkan secara kuantitatif variabel dari kumpulan data (D., 2021), variabel adalah kolom yang ada di dataset. Analisis deskriptif bisa juga dikatakan untuk melihat karakteristik dari suatu variabel untuk menjelaskan datanya. Pada penelitian ini digunakan metode analisis deskriptif diantaranya yaitu melihat persebaran data dengan menggunakan jumlah, rata-rata, dan juga korelasi diantara variabel data penelitian dan data pendukung.

Analisis korelasi merupakan uji statistika yang mengukur keeratan hubungan antara dua variabel, dimana kedua variabel tersebut dapat diukur keeratannya. Angka yang mengukur keeratan hubungan dua variabel disebut koefisien korelasi. Menurut Eddy Roflin (2021) nilai koefisien korelasi pearson (r) dapat dinyatakan sebagai berikut :

$$
\begin{aligned}
& r=\frac{\sum(x-\bar{x})(y-\bar{y})}{\sqrt{\left(\sum(x-\bar{x})^{2}\right)\left(\sum(y-\bar{y})^{2}\right)}} \ldots \ldots \ldots . . . . \\
& \text { Dimana: } \\
& r=\text { koefisien korelasi pearson } \\
& x=\text { variabel independent } \\
& y=\text { variabel dependent }
\end{aligned}
$$

Dari hasil koefisien korelasi pearson di atas maka adapun interpretasi nilai koefisien korelasi pearson sebagai berikut :

$$
-1 \leq r \leq 1 \text {. }
$$

$r$ mendekati nilai 1 , maka hubungan antar variabel $x$ dan $y$ mendekati hubungan yang kuat dan positif.

$r$ mendekati nilai -1, maka hubungan antar variabel $x$ dan $y$ mendekati hubungan yang kuat dan negatif.

$r=0$, hubungan antar variabel tidak ada 
Dengan detail rentang nilai korelasi pearson sebagai berikut menurut Sugiyono (2017) sebagai berikut

Tabel 3. Nilai Korelasi dan Keterangannya

\begin{tabular}{cc}
\hline Interval Koefisien Korelasi Pearson $(r)$ & Keterangan \\
\hline $0,00-0,199$ & Sangat Rendah \\
$0,20-0,399$ & Rendah \\
$0,40-0,599$ & Sedang \\
$0,60-0,799$ & Kuat \\
$0,80-1,000$ & Sangat Kuat \\
\hline
\end{tabular}

4) Data Visualization

Visualisasi data adalah hal yang salah satu sangat penting dalam melakukan penelitian yaitu untuk me ringkas dan visual lebih efisien dan efektif untuk dilihat. Visualisasi data ini dapat dimanfaatkan secara efektif karena grafik dari visualisasi representasinya jauh lebih kuat daripada tampilan dalam bentuk angka (Hartama, 2018). Dengan demikian, visualisasi dapat melakukan analisis untuk melihat tren, pola, dan mengidentifikasi dengan secara cepat dan optimal. Dalam penelitian ini digunakan beberapa visualisasi data yaitu diantaranya :

1. Diagram Batang

Diagram batang atau biasa disebut juga dengan bar chart adalah salah satu visualisasi yang sudah umum digunakan yaitu sebagai salah satu fungsi untuk menjelaskan suatu data, terutama data kuantitas yang memiliki kategori ataupun perbedaan secara variabel dan membandingkan antar satu batang dengan yang lainnya (Matthew N. O. Sadiku, Desember 2016).

2. Peta Choropleth

Choropleth map atau Peta Choropleth digunakan untuk memudahkan visualisasi bagaimana pengukuran bervariasi di area geografis atau menunjukkan tingkat variabilitas di suatu daerah (Hamzah Ramadhan, 2019). Dengan kata lain pengguna atau masyarakat awam dapat melihat dan membandingkan warna yang disediakan untuk mengetahui jumlah tayangan iklan penjualan dan penyewaan per Kabupaten atau kota dalam bentuk data spasial

3. Diagram Garis

Diagram garis atau line chart visualisasi data yang menunjukkan hubungan antar item, bisa juga untuk membandingkan antar periode waktu (Matthew N. O. Sadiku, Desember 2016).

4. Diagram Box plot

Diagram box plot adalah Teknik standar untuk merepresentasikan 5 angka penting yaitu seperti minimum, maksimum, kuartil atas dan bawah, dan median. Box plot juga bisa untuk melihat distribusi dari suatu data (Chen, et al., 2019). Terdapat data outlier atau tidak juga bisa dideteksi menggunakan box plot.

\section{HASIL DAN PEMBAHASAN}

\section{Jumlah Tayangan iklan Penjualan dan Penyewaan Properti di Bali}

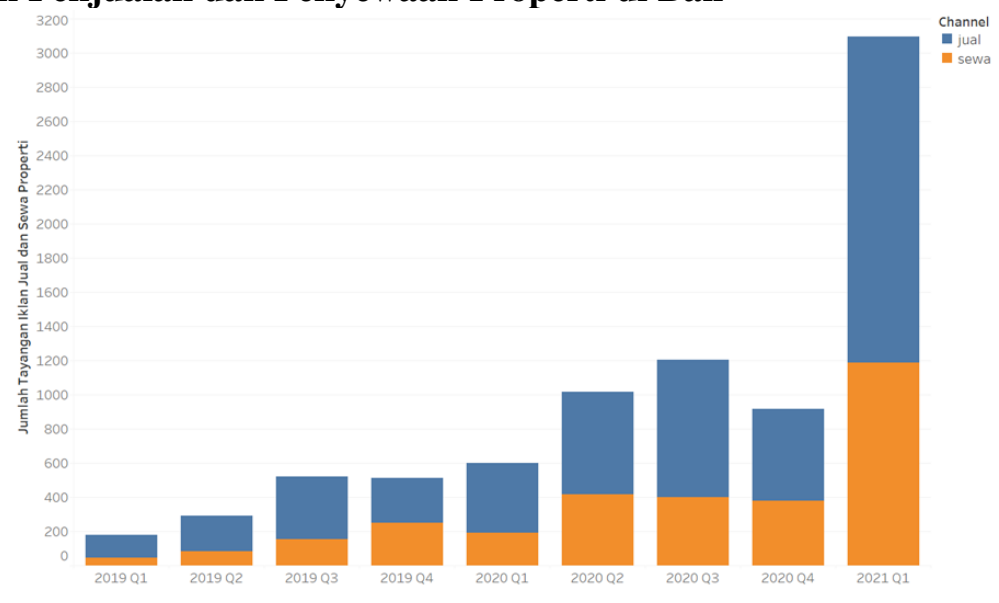

Gambar 1. Jumlah Tayangan iklan Penjualan dan Penyewaan properti dilihat dari perbedaan tipe transaksi di Bali, Triwulan I 2019- Triwulan I 2021.

Dari gambar 1 terlihat penayangan iklan penjualan dan penyewaan properti di Bali tiap triwulan mengalami kenaikan bertahap dampai dengan akhir tahun 2020 dan terlihat oleh warna biru yaitu proporsi dari iklan penjualan selalu melebihi penyewaan, karena mindset masyarakat disana mengatakan bahwa menjual 
tanah ataupun properti telah menjadi slah satunya cara untuk mendapatkan keuntungan dari perkembangan pariwisata dan sekaligus menunjukkan rendahnya pemahaman masyarakat dalam melihat peluang ekonomi dan pariwisata (Fitri Ciptosari, 2020). Kemudian terjadi kenaikan yang sangat signifikan pada awal triwulan tahun 2021 yaitu dari angka 916 langsung melonjak ke angka 3093 yaitu dimana masa ini adalah PSBB masa transisi di Pulau Jawa dan Bali.

\section{Jumlah Tayangan iklan Penjualan dan Penyewaan properti dilihat dari perbedaan tipe properti}

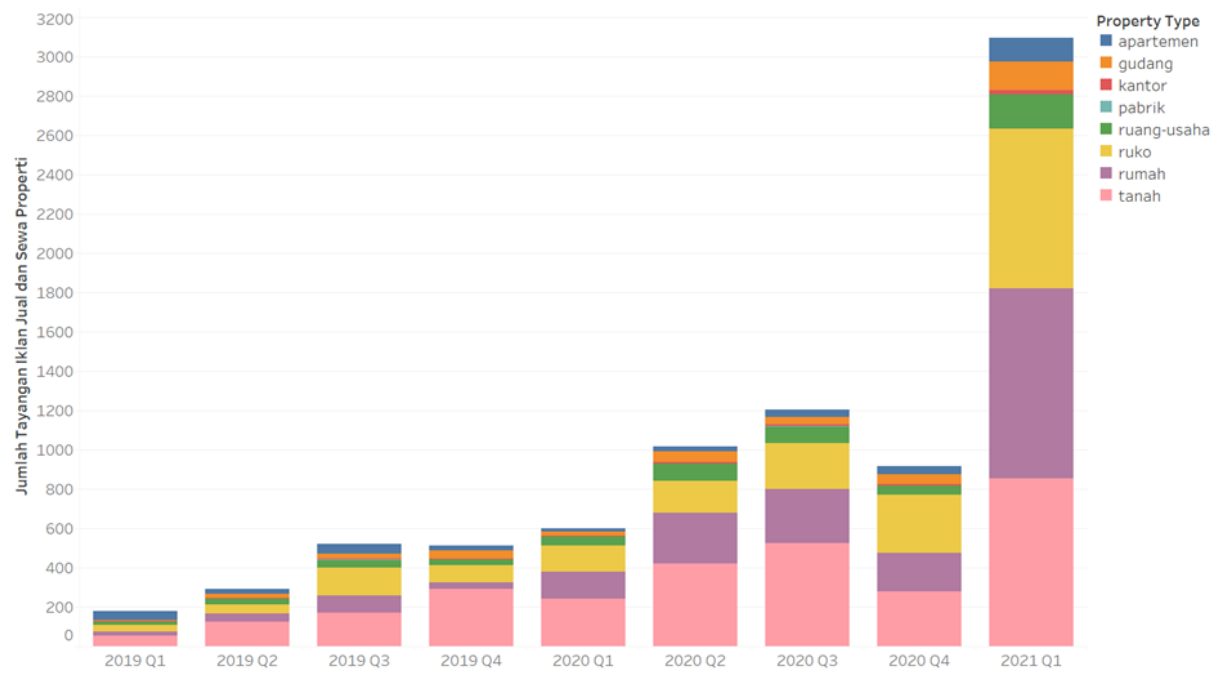

Gambar 2. Jumlah Tayangan iklan Penjualan dan Penyewaan properti dilihat dari perbedaan tipe properti di Bali, Triwulan I 2019- Triwulan I 2021

Kemudian jika ditinjau dari tipe properti terdapat paling banyak tiap triwulan adalah penjualan dan penyewaan rumah dan tanah kemudian disusul oleh ruko

\section{Peta Persebaran Jumlah Tayangan Iklan Penjualan dan Penyewaan Properti per Kabupaten di Bali}

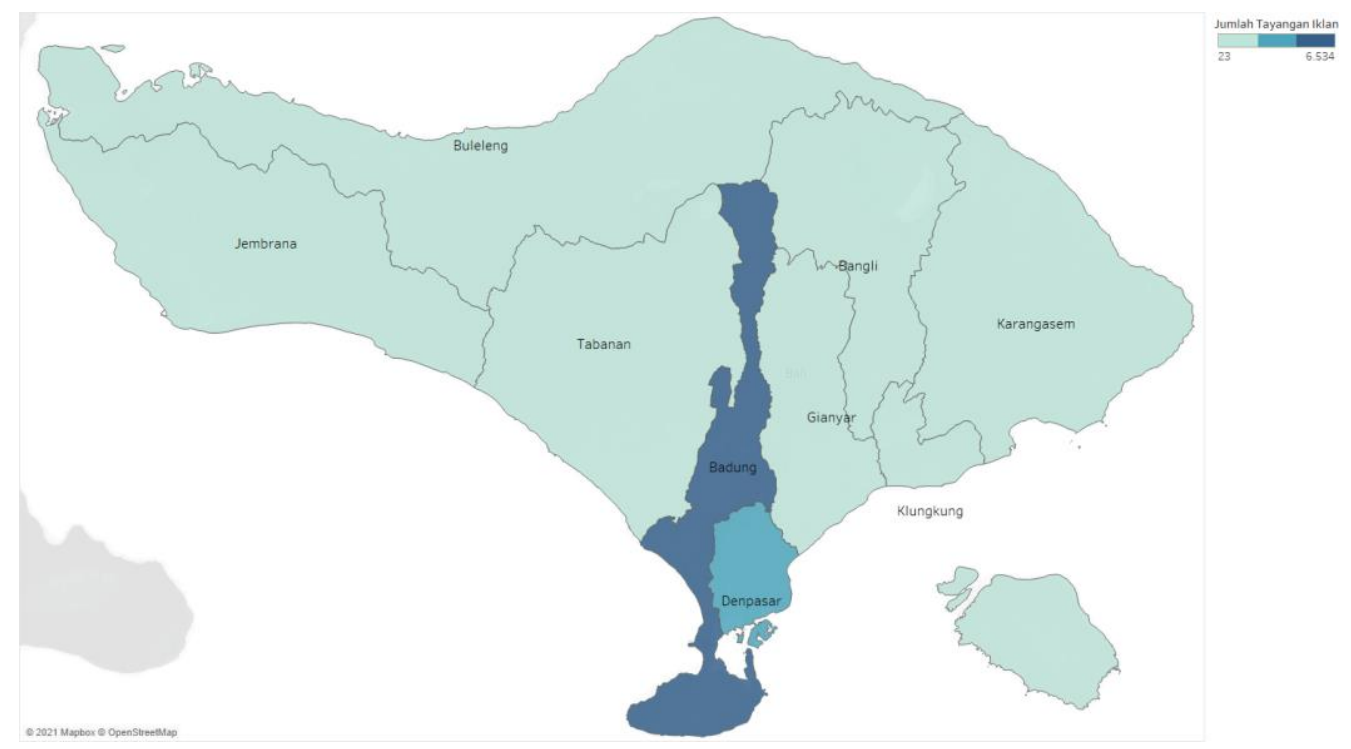

Gambar 3. Peta Persebaran Jumlah Tayangan Iklan Penjualan dan Penyewaan Properti per Kabupaten di Bali, Triwulan I 2019- Triwulan I 2021

Terlihat dari gambar 3 yaitu persebaran jumlah tayangan iklan paling banyak terdapat di Kabupaten Badung dan Kota Denpasar yaitu sebesar 6.534 dan 3.928 jumlah tayangan iklan. Kabupaten Badung telah menjadi Kabupaten yang unggul dalam daya tarik wisatawan, terutama di pantainya dan karena akses lokasi yang mudah dan terdapat akomodasi yang sangat mendukung di Kabupaten Badung (I Made Dipadewandaa, 2018). 


\section{Jumlah Tayangan Iklan Penjualan dan Penyewaan Properti Per Kabupaten di Bali Berdasarkan} Tipenya

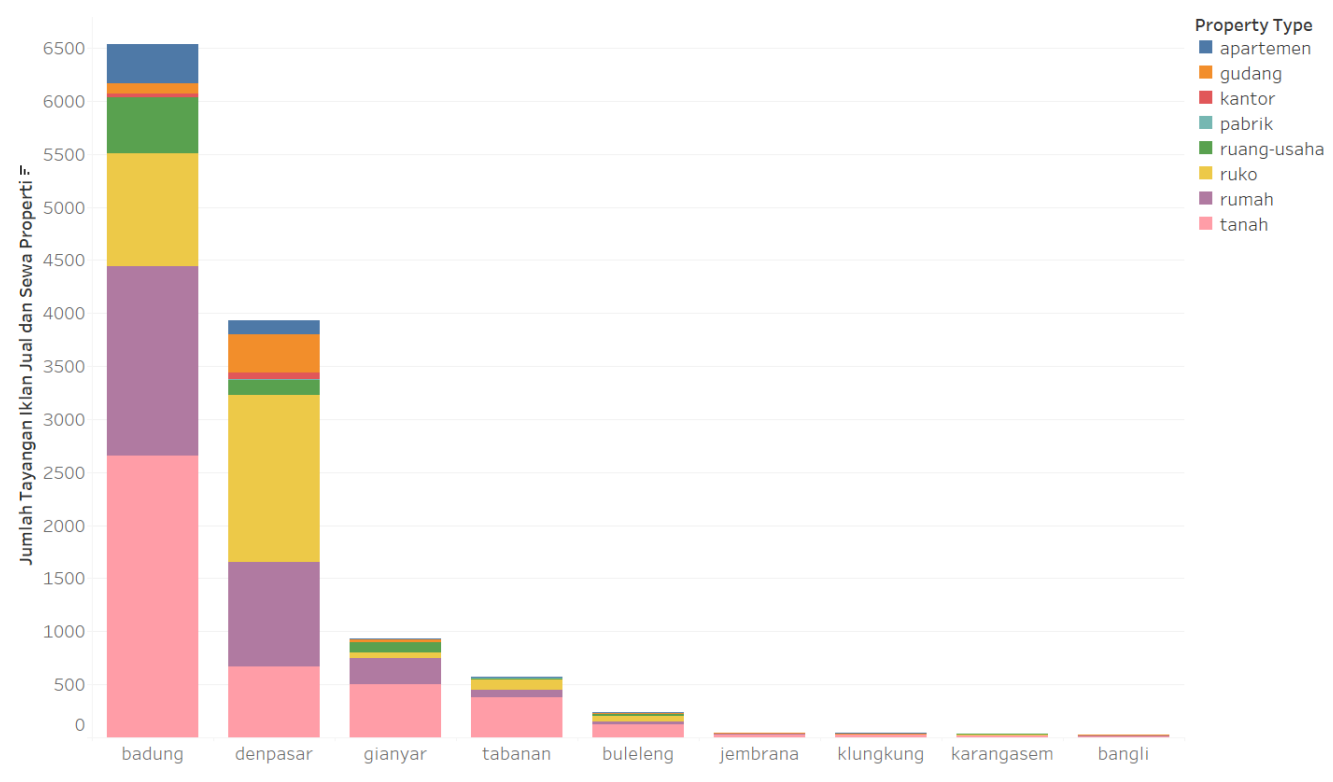

Gambar 4. Jumlah Tayangan Iklan Penjualan dan Penyewaan Properti per Kabupaten di Bali, Triwulan I 2019- Triwulan I 2021

Kemudian peneliti menghitung sesua dengan tipe properti per kabupaten, dan dihasilkan seperti gambar di atas yaitu terlihat bahwa pada Kabupaten Badung masih memiliki proporsi penjualan dan penyewaan rumah atau tanah yang tinggi, tetapi pada Kota Denpasar lebih banyak yang menayangkan tipe properti berupa ruko dikarenakan masyarakat disana banyak yang berprofesi dalam sektor pariwisata budaya dan sangat berpengaruh dalam kegiatan masyarakat disana.

\section{Jumlah tayangan iklan penjualan dan sewa properti yang bersertifikat per kabupaten/kota}

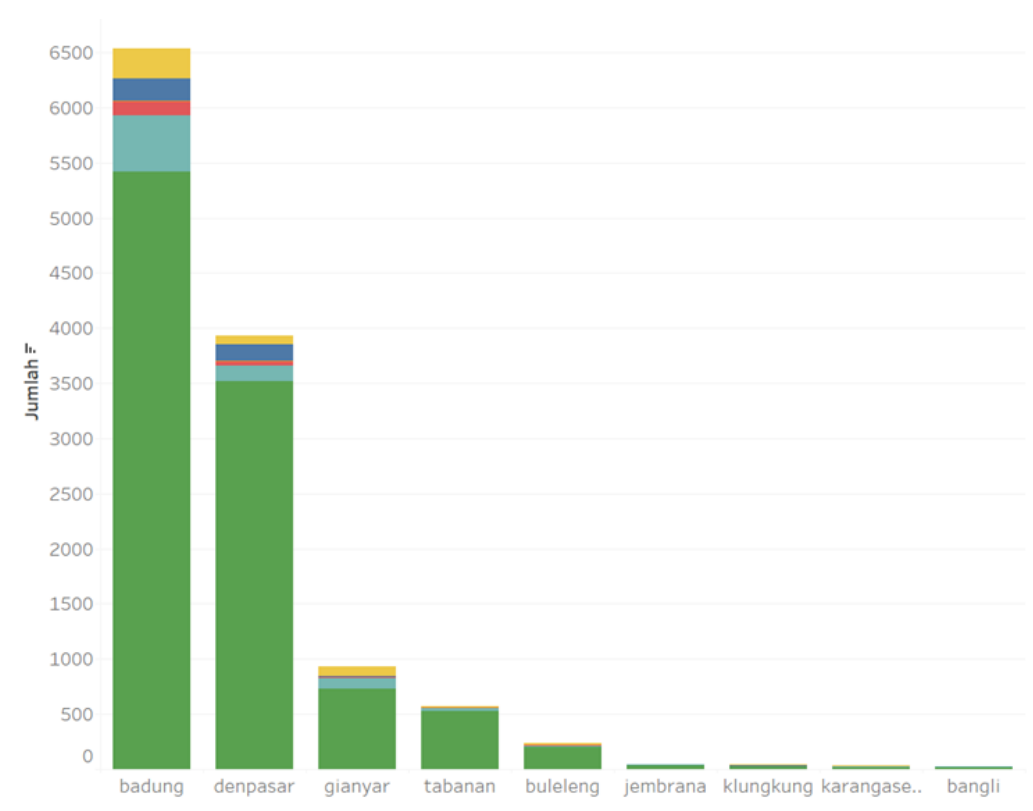

Gambar 5. Jumlah Tayangan Iklan Penjualan dan Penyewaan Properti per Kabupaten di Bali, Triwulan I 2019- Triwulan I 2021

Kemudian jika dilihat dari kepemilikan sertifikat nya semua properti di kabupaten/kota sudah cenderung memiliki SHM (Sertifikat Hak Milik), dan sedikit yang tidak memiliki sertifikat ini menunjukkan bahwa tiap kabupaten sudah cukup jelas dalam menunjukkan properti sudah tercatat dengan jelas di administrasi masingmasing kabupaten/kota. 


\section{Harga Rumah di Bali}

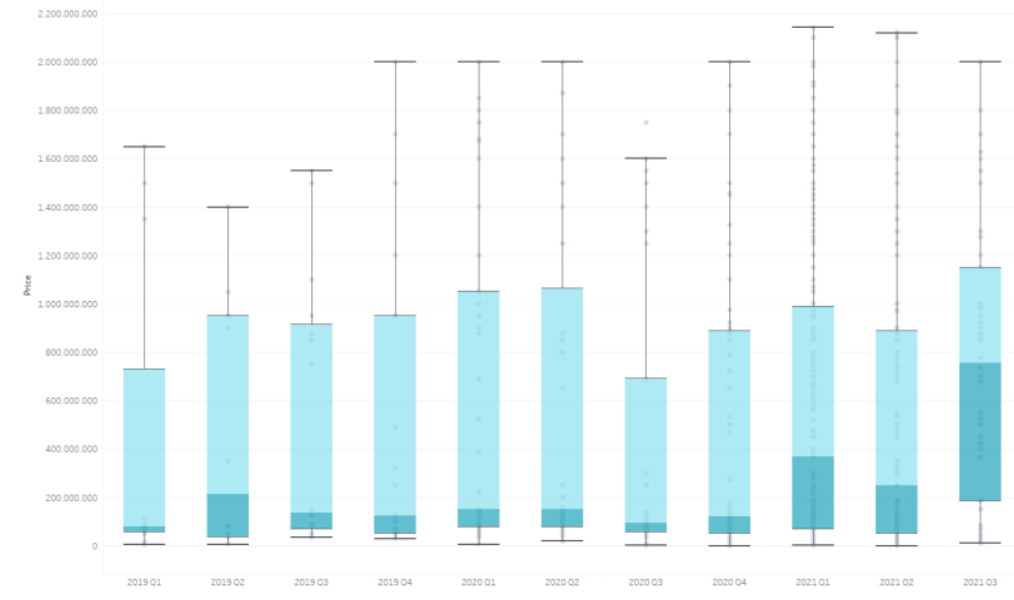

Gambar 6. Harga Rumah dengan Kategori Kurang Luas, Triwulan I 2019- Triwulan I 2021

Kategori kurang luas yang disebutkan yaitu menurut luas area/tanah kurang dari $135 \mathrm{~m}^{2}$ yaitu berupa rumah cantik dan minimalis, Rumah Semi Villa dan Kost, kemudian dihasilkan harga yang cenderung stabil dan menaik secara signifikan pada triwulan pertama dijelaskan dalam box plot bahwa median dari box plot menunjukkan kenaikan secara signifikan dari sebelumnya.

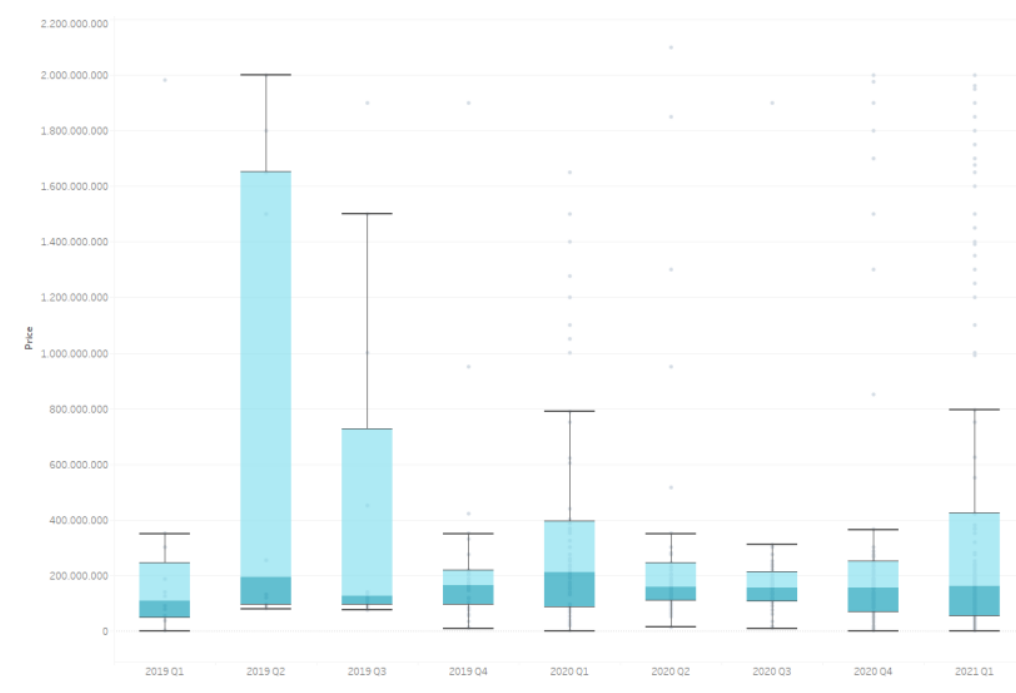

Gambar 7. Harga Rumah dengan Kategori Cukup Luas, Triwulan I 2019- Triwulan I 2021

Sedangkan pada kategori cukup luas yang disebutkan yaitu menurut luas area/tanah diantara $135 \mathrm{~m}^{2}$ dan $400 \mathrm{~m}^{2}$ terdapat distribusi harga yang cukup tinggi pada tahun 2019 triwulan ke dua seperti pada kategori sangat luas selanjutnya menunjukkan distribusi yang hampir sama

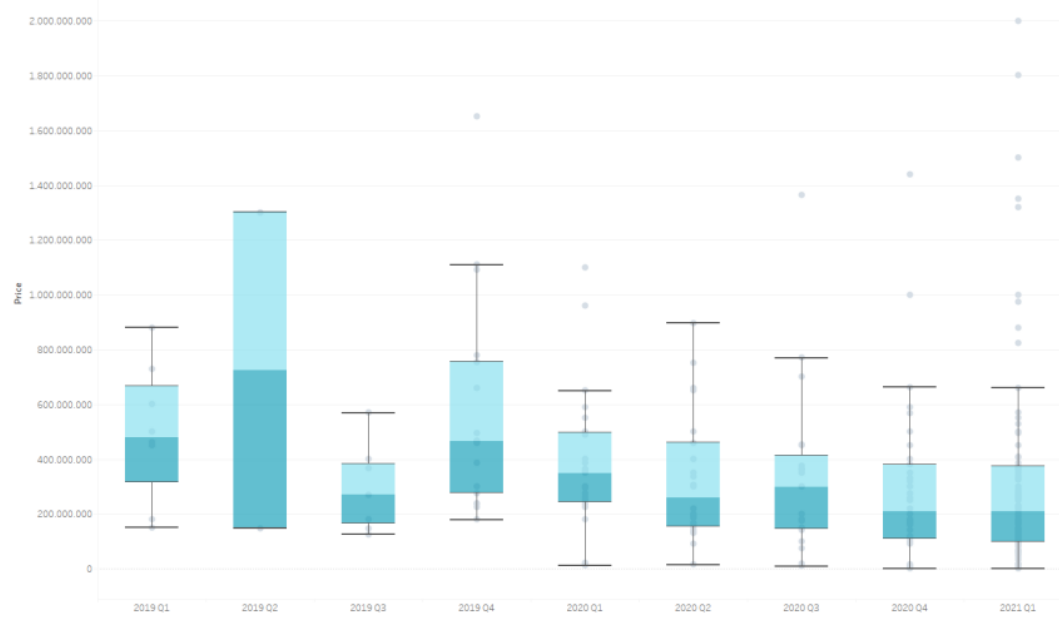

Gambar 8. Harga Rumah dengan Kategori Sangat Luas, Triwulan I 2019- Triwulan I 2021 


\section{Trend PDRB Penyediaan Akomodasi dengan Makan Minum Dengan Jumlah Tayangan Iklan} Penyewaan dan Penjualan Rumah

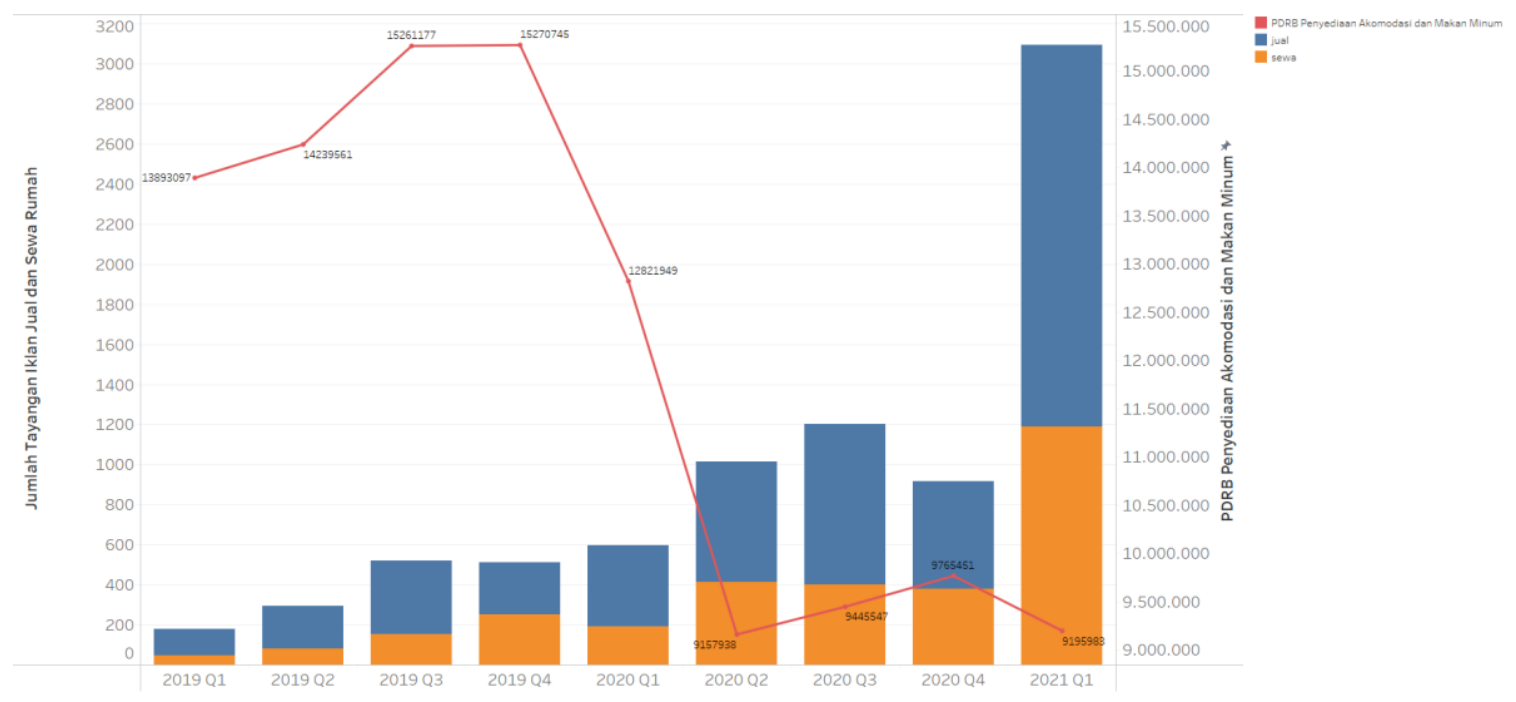

Gambar 9. Jumlah Tayangan Iklan Penjualan dan Penyewaan Properti per Kabupaten di Bali, Triwulan I 2019- Triwulan I 2021

\section{Trend PDRB Jasa Lainnya dengan Jumlah Tayangan Iklan Penyewaan dan Penjualan Rumah}

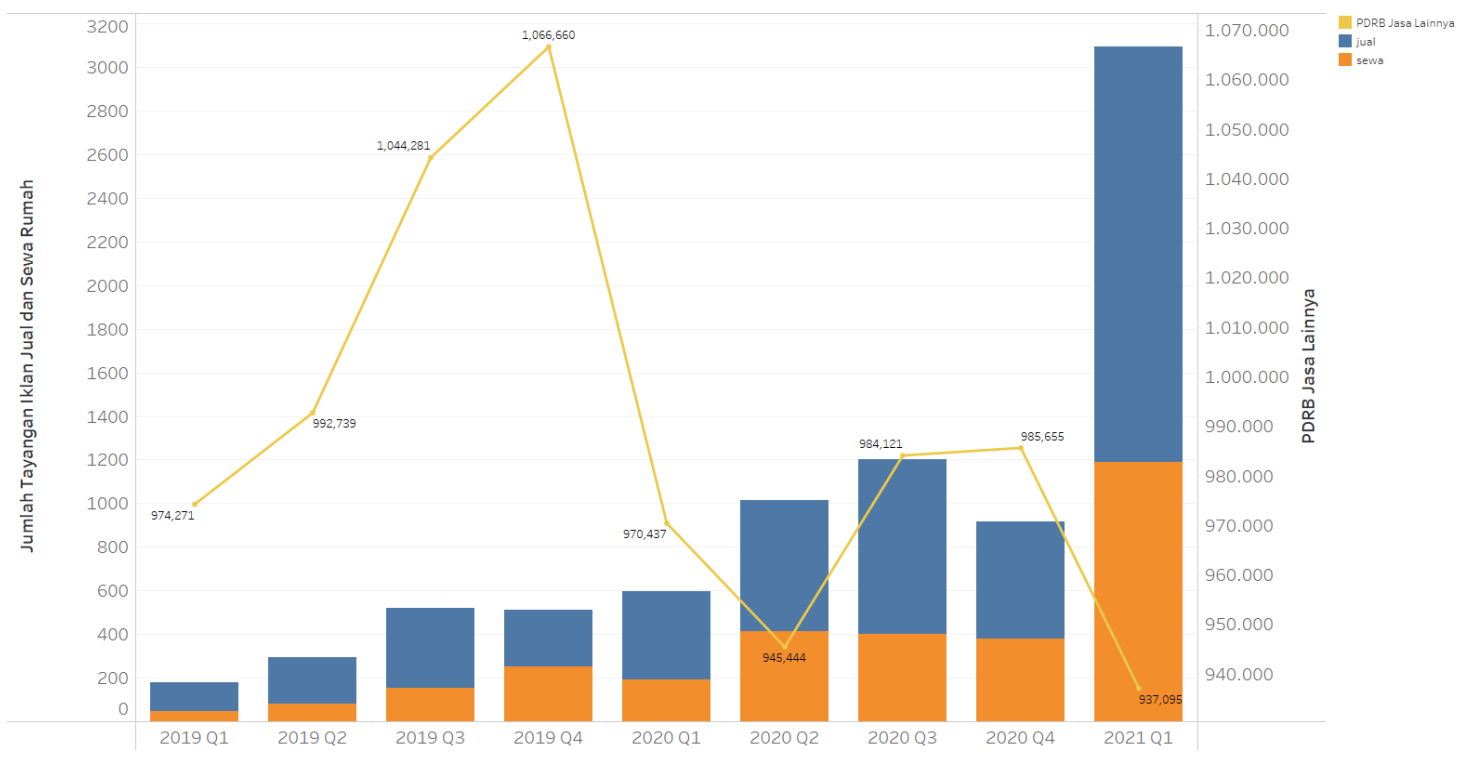

Gambar 10. Jumlah Tayangan Iklan Penjualan dan Penyewaan Properti per Kabupaten di Bali, Triwulan I 2019- Triwulan I 2021

Dengan menggunakan data (Badan Pusat Statistik 2019-2021) PDRB dengan jenis lapangan usaha : penyediaan akomodasi dan makan minum dan PDRB jenis lapangan usaha : jasa lainnya di bali adalah seperti gambar di atas jika di analisis hubungan antara PDRB dengan jumlah tayangan iklan penjualan dan penyewaan properti di Bali menunjukkan angka korelasi sebesar -0.67 dan -0.64 dimana menurut kategori koefisien korelasi pearson menunjukkan hubungan yang kuat dan dengan arah yang negatif atau tak searah yang diartikan ketika angka PDRB naik maka angka jumlah tayangan iklan menurun dan ketika PDRB naik maka angka jumlah tayangan iklan menaik seperti dijelaskan (Banker, 2020) Harga jual dan sewa sektor properti mengalami tekanan dan akan berdampak pada pemulihan pasar properti yang lebih lama. 


\section{Trend Rata-Rata Tingkat Penghunian Kamar dengan Jumlah Tayangan Iklan Penyewaan dan Penjualan Rumah}

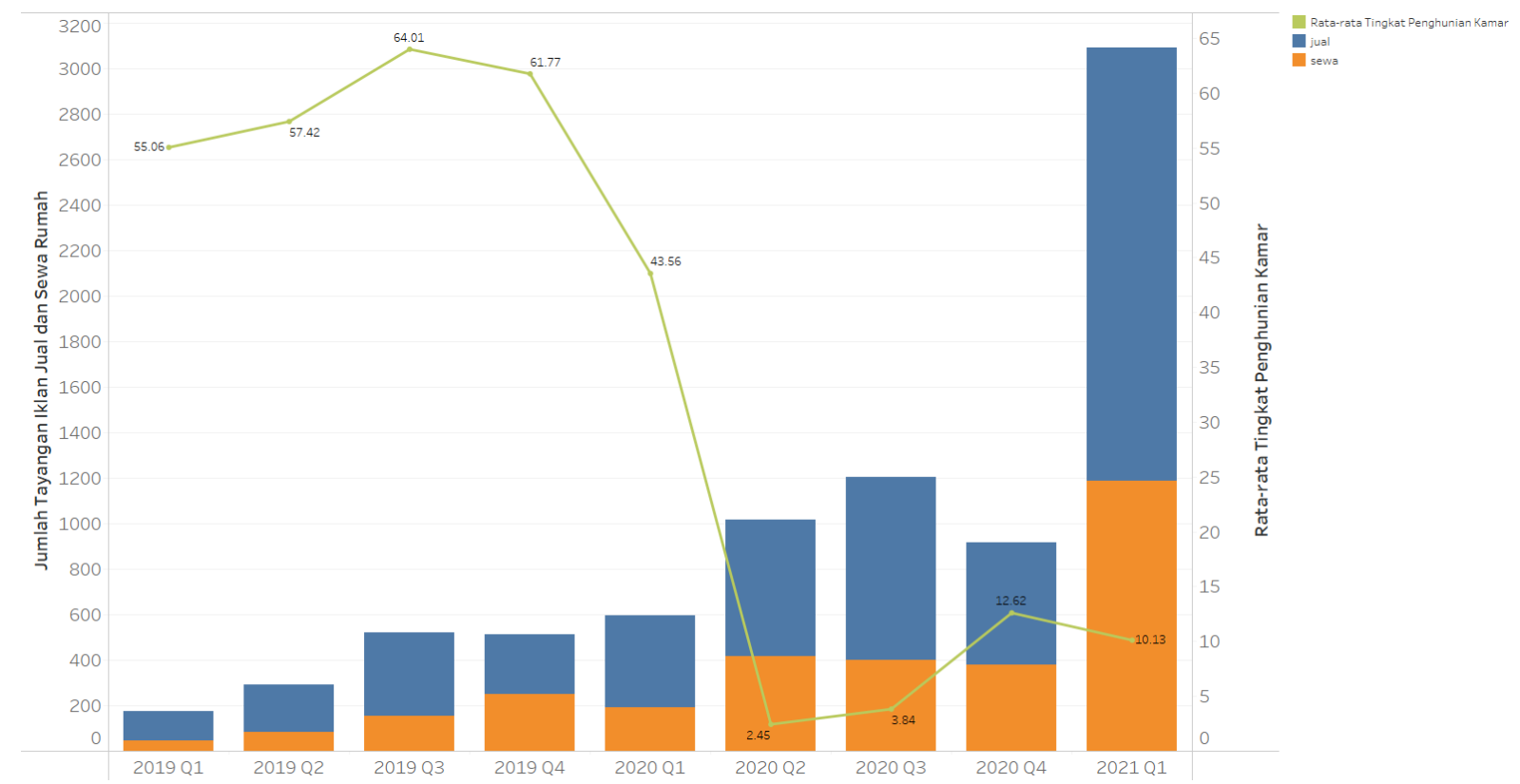

Gambar 12. Jumlah Tayangan Iklan Penjualan dan Penyewaan Properti per Kabupaten di Bali, Triwulan I 2019- Triwulan I 2021

Kemudian berdasarkan data Badan Pusat Statistik, Tingkat penghunian Kamar pada awal tahun 2020 mengalami penurunan yang sangat signifikan yaitu dari 43,56 ke 2,45 angka ini dihasilkan dari rata-rata per triwulannya dimana pada tahun berikut adalah masa PSBB dilakukan di Pulau Jawa dan Bali yaitu pada bulan Maret sampai April 2020 yaitu pada triwulan ke dua, setelah itu TPK Kembali menaik secara bertahap dan kembali di angka 12,62 dan kembali menurun di awal tahun 2021 karena diberlakukan PSBB kembali di Pulau Jawa dan Bali.

Setelah itu jika dilihat hubungan antar TPK dan jumlah tayangan iklan penjualan dan penyewaan properti dihasilkan nilai korelasi sebesar -0.53. yaitu menunjukkan kekuatan hubungan yang sedang dan tidak searah yang artinya Ketika TPK naik maka jumlah tayangan iklan turun, karena pendapatan pada sektor pariwisata sudah cukup naik maka iklan penjualan akan menurun dan masyarakat berfokus ke sektor pariwisata menurut Suwanto (2020) Kegiatan kepariwisataan merupakan salah satu sumber pendapatan nasional maupun daerah yang cukup potensial.

\section{KESIMPULAN}

Berdasarkan hasil dan pembahasan yang sudah dijelaskan sebelumnya maka dapat disimpulkan beberapa hal yaitu ketika diberlakukan PSBB dalam menghadapi pandemic Covid-19 masyarakat di Bali yang pendapatannya sangat bergantung di sektor pariwisata cenderung menjual atau menyewakan propertinya untuk memulihkan keadaan pendapatan mereka dan tipe properti yang dijual yaitu rumah dan tanah disusul oleh ruko terutama di kota Denpasar yaitu masyarakatnya bergerak di sektor pariwisata budaya. Kemudian berdasarkan luas area atau tanah di setiap triwulannya dari tahun 2019-2021 cenderung menaik harganya di awal tahun 2021 untuk kategori kurang luas yaitu tipe bangunan rumah minimalis dan cantik dll , kemudian untuk kategori lainnya sama-sama memiliki distribusi harga yang menaik pada triwulan ke dua tahun 2019 dimana untuk tayangan iklannya lebih sedikit dari kategori kurang luas sehingga dirasakan cukup tidak ada perubahan untuk harganya.

Selanjutnya yaitu hubungan antara PDRB jenis lapangan usaha : penyediaan akomodasi dan makan minum serta jasa lainnya dihasilkan nilai korelasi yang kuat dan tak searah yaitu ketika PDRB naik maka tayangan iklan akan menurun dan harga jual dan sewa sektor properti mengalami tekanan dan akan berdampak pada pemulihan pasar properti yang lebih lama, kemudian hubungan TPK dengan jumlah tayangan iklan juga menunjukkan hasil hubungan yang sedang dan tak searah seperti dengan yang sebelumnya karena pendapatan menurun masyarakat akan cenderung menjual properti mereka dikarenakan kegiatan pariwisata di daerah Bali merupakan salah satu sumber pendapatan nasional atau daerah yang cukup potensial. 


\section{DAFTAR PUSTAKA}

Banker, S. A.-C. (2020). Ringkasan Pasar Properti di Indonesia di Tengah Pandemi COVID-19. Jakarta.

Chen, X., Shen, L., Sha, Z., Liu, R., Chen, S., Ji, G., \& Tan, C. (2019). A Survey of Multi Space Techniques in Spatio-Temporal Simulation Data Visualization. Visual Informatics Volume 3, 46-55. https://doi.org/10.1016/j.visinf.2019.08.002

Christine Ullyana, H. K. (2016). Harga Properti Residensial \& Pembiayaan Pemilikan Rumah Perbankan Syariah dan Konvensional. Jurnal Al-Muzara'ah.

D., S. (2021). Descriptive Statistics In : Advanced Analytics with Transact-SQL. Apress, Berkeley. https://doi.org/10.1007/978-1-4842-7173-5_1

Eddy Roflin, F. E. (2021). KUPAS TUNTAS ANALISIS KORELASI. Jawa Tengah: Penerbit NEM.

Fitri Ciptosari, T. S. (2020). Pariwisata Residensial : Perkembangan Pariwisata di Delha Rote. Journal of Humanity \& Social Justice Volume 2 Issue 1.

Hamzah Ramadhan, D. S. (2019). SISTEM INFORMASI GEOGRAFIS KEPENDUDUKAN KECAMATAN. Bina Darma Conference on Computer Science 2019. Fakultas Ilmu Komputer Universitas Bina Darma.

Hartama, D. (2018). Analisa Visualisasi Data Akademik Menggunakan Tableau Big Data. Jurnal Riset Sistem Informasi Dan Teknik Informatika (JURASIK) Volume (3) , 46-55. http://dx.doi.org/10.30645/jurasik.v3i0.65.g57

I Made Dipadewandaa, I. G. (2018). Perkembangan Pariwisata di Daya Tarik Wisata Pantai Berawa Kabupaten Badung : Studi Kasus-Dampak Pola Konsumsi Masyarakat di Pantai Berawa. Jurnal Destinasi Pariwisata Volume 06 No.2.

Matthew N. O. Sadiku, A. E. (Desember 2016). Data Visualization. Journal of Engineering Research and Advanced Technology (IJERAT) Volume 02 Issue 12.

Murphy, S. (2016). Data Visualization and Rapid Analytics: Applying Tableau Desktop to Support Library Decision-Making. Journal of Web Librarianship, 465-476.

Statistik, B. P. (2020). Badan Pusat Statistik. Retrieved from Badan Pusat Statistik Provinsi Bali: https://bali.bps.go.id/indicator/16/106/1/banyaknya-wisatawan-mancanegara-bulanan-ke-balimenurut-pintu-masuk.html

Sugiyono. (2017). Metode Penelitian Kuantitatif, Kualitatif, dan R\&D. Bandung: Alfabeta.

Suwanto. (2020). Hubungan Jumlah Kunjungan Wisatawan Mancanegara Dengan Rata-rata Tingkat Penghunian Kamar Hotel Provinsi DKI Jakarta Tahun 2012-2018. Jurnal Kepariwisataan Indonesia 14.

Utama, I. G. (2016). Pemasaran Pariwisata. Bali: Universitas Dhyana Pura.

Wahyu Calvin Frans Mariel, K. S. (2021). Utilization of Big Data through Digital Platform to. ICACSIS Conference 2021. Jakarta.

Badan Pusat Statistik Provinsi Bali.(2019). Berita Resmi Statistik : Pertumbuhan Ekonomi Bali Semester I 2019. Produk Domestik Regional Bruto (PDRB) Provinsi Bali No. 54/08/51/Th. XIII, 5 Agustus 2019.Badan Pusat Statistik Provinsi Bali

Badan Pusat Statistik Provinsi Bali.(2019). Berita Resmi Statistik : Pertumbuhan Ekonomi Bali Triwulan III2019. Produk Domestik Regional Bruto (PDRB) Provinsi Bali No. 72/11/51/Th. XIII, 5 November 2019.Badan Pusat Statistik Provinsi Bali

Badan Pusat Statistik Provinsi Bali.(2020). Berita Resmi Statistik : Pertumbuhan Ekonomi Bali Tahun 2019. Produk Domestik Regional Bruto (PDRB) Provinsi Bali No. 13/02/51/Th. XIV, 5 Februari 2020.Badan Pusat Statistik Provinsi Bali

Badan Pusat Statistik Provinsi Bali.(2020). Berita Resmi Statistik : Pertumbuhan Ekonomi Bali Semester I2020. Produk Domestik Regional Bruto (PDRB) Provinsi Bali No. 51/08/51/Th. XIV, 5 Agustus 2020.Badan Pusat Statistik Provinsi Bali

Badan Pusat Statistik Provinsi Bali.(2019). Berita Resmi Statistik : Pertumbuhan Ekonomi Bali Triwulan III2020. Produk Domestik Regional Bruto (PDRB) Provinsi Bali No. 68/11/51/Th. XIV, 5 November 2020.Badan Pusat Statistik Provinsi Bali

Badan Pusat Statistik Provinsi Bali.(2020). Berita Resmi Statistik : Pertumbuhan Ekonomi Bali Triwulan IV2020. Produk Domestik Regional Bruto (PDRB) Provinsi Bali No. 14/02/51/Th. XV, 5 Februari 2021.Badan Pusat Statistik Provinsi Bali

Badan Pusat Statistik Provinsi Bali.(2021). Berita Resmi Statistik : Pertumbuhan Ekonomi Bali Triwulan I2021. Produk Domestik Regional Bruto (PDRB) Provinsi Bali No. 32/05/51/Th. XV, 5 Mei 2021.Badan Pusat Statistik Provinsi Bali 